\title{
Ziarah Wali di Indonesia dalam Perspektif Pilgrime Studies
}

\author{
Anwar Masduki \\ Sekolah Tinggi Ilmu Syariah wal Aqidah (STISA) Manonjaya, \\ Tasikmalaya \\ interreligiousity@gmail.com
}

\begin{abstract}
Pilgrimage studies is multidisciplinary studies in religious studies involving many perspectives and approaches in the social sciences. Therefore, it cannot be separated from the development of other studies, particularly tourism studies that leads to the current study on religious tourism. This article is a literature review generally tracing the development of theoretical tendencies of the pilgrimage studies. Based on an understanding of some theoretical tendencies, this article attempts to look at and examine the emerging trends in the study of saint's pilgrimage in Indonesia, as one of the variants in pilgrimage studies. The study attempts to scrutiny (1) the dominant theories of the pilgrimage studies, (2) the study of saint's pilgrimage in Indonesia, continued with (3) what aspects relate to the study of saint's pilgrimage, and (4) which are the focus of discussions that still need to be discussed and explored relating to the study of saint's pilgrimage in Indonesia. The results show that the pilgrimage studies experience recent theoretical developments and trends that emphasize postmodern reasoning, which makes pilgrimage studies vary with a great influence on the study of pilgrimage to the tourism studies.
\end{abstract}

Keywords: Pilgrimage Studies, Tourism Studies, Postmodern, the Study of Saint's Pilgrimage, Indonesian Islam. 


\section{Pendahuluan}

Pilgrimage studies (studi ziarah) merupakan salah satu kajian penting dalam kajian kehidupan keagamaan manusia di dunia dewasa ini. Kemunculan Pilgrimage studies tidak bisa dilepaskan dari pengaruh religious studies, sebagai sebuah kajian yang membahas fenomena keberagamaan sebagai hal yang bersifat multi-interpretatif, lintas budaya dan masuk sangat jauh ke dalam kehidupan sehari-hari para pemeluk agama. Tidak bisa disangkal lagi, agama memang masih menjadi nafas penting, entah dalam aspek ritual maupun proyeksi dan praktik dari nilai-nilai dan ajaran agama dalam kehidupan para penganut agama itu sendiri. Dari barat sampai ke timur, dari Washington DC sampai ke pedalaman Kalimantan, agama dengan segala varian pengertiannya masih dan akan terus menjadi objek yang menarik untuk dikaji dan diteorikan.

Pada kondisi yang sepenting itu, pilgrimage studies menempati posisi penting untuk meneliti kehidupan beragama secara lebih mendalam. Fenomena ziarah sendiri sudah menjadi fenomena global di mayoritas semua agama, baik agama minoritas lokal seperti Zoroaster di Iran maupun agama-agama mayoritas dunia, baik yang Abrahamik dan non-Abrahamik. ${ }^{1}$ para pemeluk agama Hindu, Budha, Yahudi, Kristen, dan Islam mempunyai waktu-waktu khusus untuk melakukan ziarah ke situs-situs yang mereka anggap suci. Sebagai contoh, Muslim akan mengunjungi Makkah dan Madinah untuk melakukan Haji dan Ziarah ke makam Nabi pada bulan Dzulhijjah, penganut Budha akan pergi Lhasa, Katolik ke Roma, dan para pemeluk Hindu ke sungai Gangga setiap tahunnya.

Pertanyaan yang mengemuka kemudian adalah apa dan bagaimana sebuah kegiatan atau ritual itu bisa kita sebut sebagai ziarah? Setelah mencari dan mengkaji beberapa definisi pilgrimage, Stoddard ${ }^{2}$

\footnotetext{
1 Surinder M. Bhardwaj dan Gisbert Rinschede, "Pilgrimage: A World-wide Phenomena," dalam S.M. Bhardwaj dan G. Rinschede (eds.), Pilgrimage in World Religion (Berlin: Reimer, 1988), 11-13.

2 Robert Stoddard, "Defining and Classifying Pilgrimage", dalam Robert H. Stoddard and Alan Morinis (eds.), Sacred Places, Sacred Spaces: The Geography of Pilgrimages, Journal of Geoscience and Man, vol. 34, 41-60 (Dept. of Geography and Anthropology, Louisiana State University, Baton Rouge, LA, 1997).
} 
mengklasifikasi sebuah kegiatan bisa disebut pilgrimage jika, mengandung beberapa aspek di antaranya: (1) jarak (distance of movement), (2) motivasi (motivation), (3) tempat jujugan (destination) dan (4) jumlah pengunjung (magnitude). Dengan mengkaji empat aspek itu, Stoddard kemudian mendefinisikan pilgrimage sebagai:

"Sebuah kegiatan ke tempat-tempat suci yang dilakukan oleh banyak orang, dilakukan lebih lama daripada sebuah perjalanan lokal biasa, dan dianggap sebagai tindakan ketaatan beragama."3

Definisi dan aspek yang diutarakan Stoddard ini jelas lebih luas daripada yang disepakati secara umum oleh para ahli geografi ziarah. Para geografer sejarah menganggap ada 2 (dua) konsep penting yang selalu terkait dengan pilgrimage; yakni sirkulasi (circulation) dan tempat (place) ${ }^{4}$. Hal ini mengindikasikan bahwa, pilgrimage sesuai dengan makna asalnya yang berarti perjalanan (travelling), memang akan selalu terkait dengan pergerakan manusia dari satu tempat asal menuju ke tempat penziarahan yang ingin dikunjungi. Dua konsep ini saling berkaitan dan tidak bisa dipisahkan satu dengan yang lain. Seseorang yang menunaikan ibadah haji dari Indonesia (tempat asal) harus menempuh perjalanan atau perpindahan yang bersifat fisik (sirkulasi) ke Mekkah dan Madinah, sebagai tempat akhir yang menjadi rujukan.

Konsep "sirkulasi" di sini kemudian menjadi sinonim dengan konsep lain yang belakangan menjadi isu dominan dari pilgrimage studies dewasa ini, yakni mobilitas. Mobilitas menjadi sorotan terkini dari banyak peneliti pilgrimage studies di dunia, ketika ada kebutuhan mendesak bagi mereka untuk memahami kaitan antara pilgrimage dengan wisata (tourism). ${ }^{5}$ Tidak dapat disangkal, studi tentang tourism memang mirip dan memberikan kesan yang sama dengan pilgrimage, dimana konsep "perjalanan" dan "tempat" menjadi titik temunya.

Merujuk definisi Stoddard, pasti kita akan segera menyadari perbedaan mendasar dari pilgrimage dan tourism. Dengan melihat aspek

\footnotetext{
${ }^{3}$ Ibid, 49.

4 Hiroshi Tanaka, "On the geographic study of pilgrimage places," dalam S.M. Bhardwaj dan G. Rinschede (ed.), Pilgrimage in World Religion (Berlin: Reimer, 1988), 22.

${ }^{5}$ Lihat misalnya Ellen Badone \& Sharon R. Roseman (ed.), Intersecting Journeys: The Anthropology of Pilgrimage and Tourism (Illionis: University of illionis Press, 2004).
} 
motivasi orang untuk melakukan wisata atau ziarah, kita akan melihat perbedaannya secara jelas. Meminjam term Durkheimian, ziarah menekankan motivasinya pada isu spiritualitas dan atau religiositas yang bersifat sakral dan ukhrawi, sedangkan penekanan pada kajian wisata lebih menekankan diri pada isu kesenangan (leisure) dan atau liburan (vacation) yang bersifat profan dan duniawi.

Meski begitu, dua penekanan yang berlawanan ini ternyata banyak digugat oleh para peneliti terkini pilgrimage studies. Studi terdahulu, sebagaimana ditunjuk oleh Eade ${ }^{6}$, dituding membawa aroma biner yang begitu kentara. Pendekatan teoretis dan praktik penelitian perbandingan biner seperti sakral vs profan, ukhrawi vs duniawi dan/atau spiritual vs jasmaniah telah membuat pilgrimage studies gagal untuk menjawab kompleksitas persoalan ziarah dewasa ini. Pada akhirnya, hal itu yang membuat para peneliti gagal untuk memahami fenomena penziarahan secara komprehensif. ${ }^{7}$

Kondisi-kondisi di atas mengindikasikan bahwa konsep pilgrimage juga selalu berkembang. Artinya, konsepsi geografis yang mengaitkan mobilitas atau sirkulasi dengan tempat penziarahan masih mendapat banyak pengayaan dari praktik ritual penziarahan itu sendiri. Makalah ini, dengan demikian, akan berupa kajian literatur yang berusaha membahas: (1) teori-teori dominan dalam kajian ziarah, kemudian mengerucut pada (2) kajian ziarah wali sebagai salah satu variannya di Indonesia, dilanjut dengan (3) aspek-aspek apa saja yang terkait dengan ziarah wali serta (4) lokus pembahasan mana saja yang masih perlu dibahas dan didalami terkait dengan kajian ziarah wali di Indonesia. Makalah ini akan ditutup dengan catatan kritis dan kesimpulan, serta peluang kajian lanjut yang bisa dielaborasi dari pilgrimage studies ala Indonesia ke depannya.

6 Jhon Eade, "The Expanding Field of Pilgrimage Studies: Beyond Binaries, Commentary", dalam Journal of Tourism, Vol. 59 No. 3/ 2011/ 387-389.

7 Lihat misalnya kritik dari Agehananda Bharati, "Theoretical Approaches to the Anthropology of Pilgrimage," dalam Mahipal Buriya dan S.M. Michael (eds.), Anthropology as a Historical Science (Indore, India: Sat Prakashan Sanchar Kendra, 1984), 203-222. 


\section{Teori-teori dominan dalam Pilgrimage Studies}

Teori Victor W. Turner ${ }^{8}$ tentang Communitas menjadi pintu masuk penting dalam memahami pilgrimage studies. Terinspirasi dari karya van Gennep tentang rite de passage, Turner menunjuk dua sisi penting dalam ziarah, yakni simbolisasi dan performa ritual yang bisa digunakan untuk menganalisis struktur sosial kehidupan masyarakat. Berdasarkan dua hal itu, Turner menteorikan adanya kondisi anti-structure, dimana orang yang berziarah akan lepas atau melepaskan diri secara sadar dan tidak sadar dari struktur atau latar belakang dan ikatan sosial kulturalnya masing-masing. Keadaan ini berangkat dari kondisi liminal, kondisi dimana orang mengalami ambang pergantian dari kesadaran biasa menuju kesadaran spiritual yang akan dialami dalam proses ziarah. Dalam kondisi anti-structure itulah, para peziarah menemukan diri di tengahtengah communitas, kondisi dan situasi yang berisi sekelompok manusia yang setara, terlepas dari kelas dan latar belakang sosial masing-masing. Sejalan dengan tempat dan waktu ziarah yang terbatas, kondisi atau pengalaman communitas juga bersifat terbatas dan temporer, hanya akan terjadi ketika orang menjalani ritual dan perjalanan penziarahan itu sendiri.

Populernya karya Turner bukan berarti sepi dari kritik. Teori Kontestasi (Contestation) menjadi antitesis dari Communitas, dengan menyodorkan bukti adanya fenomena penziarahan yang tidak cocok dengan tesis awal Turnerian. Alih-alih melihat fenomena ziarah sebagai peleburan atau penihilan latar belakang dan ikatan sosial masing-masing, mereka melihat bahwa penziarahan justru semakin menguatkan perbedaan kelas dan latar belakang sosial itu sendiri. Bharati ${ }^{9}$ menunjukkan itu dalam penelitiannya pada peziarah Hindu di India, di mana para peziarah masih saja tidak mau bercampur dengan para peziarah lain yang bukan satu kasta, dan pengelompokan privasi yang kuat (strong circle of privacy) dari masing-masing peziarah, sebagai kompensasi ketiadaan "permanen struktur" yang biasanya mereka alami atau punyai di desa atau kota masing-masing.

\footnotetext{
8 Victor W. Turner, The Ritual Process, Structure and Anti-structure, 2nd Edition (New Jersey: Transaction Publication, 2008), 94-130.

${ }_{9}$ Bharati, Theoretical Approaches, 203-204.
} 
Menguatkan itu, Hiroshi Tanaka ${ }^{10}$ juga memberikan bukti dari kegiatan ziarah di Jepang. Meneliti ritual, rute dan tempat para peziarah, Tanaka, meski tidak seluruhnya, menunjukkan betapa simbol dan tempat ritual ziarah di Jepang memberi gambaran berbeda dari teori yang dikembangkan Turner. Jika Turner mengandaikan pusat situs ziarah sebagai "the centre out there", lokasi dan kehidupan keseharian peziarah, maka Tanaka menggugat itu dengan mencontohkan lokasi dan rute 88 candi yang terletak di dekat perkampungan. Secara ringkas, pandangan Turner masih sangat bersifat universal, sementara setiap fenomena ziarah menawarkan partikularitas lokal dan kekhususan lain yang berbeda-beda. ${ }^{12}$

Selain Bharati dan Tanaka, Sallnow dan Eade $^{13}$ mengeditori sebuah buku yang melihat ziarah sebagai media kontestasi pemaknaan antara para peziarah dan orang-orang yang hidup di sekitar lokasi penziarahan. Mengambil studi kasus pada penziarahan umat Kristen di Lordes, Italia, Jerusalem, Srilanka dan Peru, kumpulan tulisan ini memberi pemahaman yang sangat baik dalam hubungan antara manusia dan hal yang sakral, serta aneka ragam reaksi dan praktik yang mengemuka, baik itu berupa akomodasi sampai bahkan kontestasi yang terjadi dalam praktik ziarah. Buku ini jelas-jelas menolak klaim Communitas Turnerian yang mereka anggap sangat strukturalis, di mana manusia dengan sukarela berlepas atau melepaskan diri struktur kehidupan sehari-hari mereka. ${ }^{14}$ Alih-alih saling melebur, para peziarah dan orang yang hidup di sekitar lokasi penziarahan malah menunjukkan indikasi perbedaan dalam memahami dan memaknai simbol dan ritual ziarah.

Lebih lanjut, pola pikir postmodernitas ternyata juga ikut memberi andil pada transformasi gelombang ketiga dari perkembangan

\footnotetext{
10 Tanaka, "On the Geograpic Study", 27-28.

11 Victor Turner, "The Center Out There: Pilgrim's Goal”, dalam Journal History of Religions, Vol. 12, 1973, 191-230.

12 Ibid, 35.

13 Jhon Eade dan Michael J. Sallnow, Contesting the Sacred, The Anthropology of Pilgrimage (Illionis: University of Illionis Press, 2000).

${ }^{14}$ Ibid.
} 
teori-teori pilgrimage studies. Collins-Kreiner ${ }^{15}$ membagi transformasi perkembangan itu pada 5 (lima) kategori penting, yakni: (1) dari diferensiasi menuju de-diferensiasi, (2) perluasan area penelitian, (3) dari elemen eksternal dan general menuju pengalaman batiniah individu, (4) perpindahan dari objek ke subjek, dari objektivitas menuju subjektivitas, serta (5) dari pendekatan Either/or menjadi pendekatan Both-and.

Dari kelima kategori itu, kita mengetahui bahwa isu binaritas memang menjadi hal yang dikritik oleh para peneliti posmodernis ini, selain juga menerima dan mengapresiasi kebebasan lebih bagi individu untuk memaknai dan menikmati prosesnya dalam berziarah. Berpegangan pada kelima kategori itu pula, Collins-Kreiner menunjukkan bahwa transformasi paradigma dari pilgrimage studies sangat dipengaruhi oleh studi tentang mobilitas dan wisata (mobility and tourism). Baginya, perbedaan antara seorang peziarah dengan seorang turis sudah semakin samar, dengan meningkatnya persamaan dalam hal kebutuhan untuk perpindahan ruang dan hasrat perasaan untuk mengunjungi tempat-tempat yang dianggapnya bermakna secara spiritual. Dengan demikian, menurut Collins-Kreiner, transformasi turisme menjadi fokus dari studi penziarahan terkini dan menawarkan sebuah perspektif ala postmodern yang lebih cenderung kepada pengalaman subyektif peziarah/turis, serta menawarkan sebuah interpretasi yang berwatak multidisipliner. ${ }^{16}$

Dalam kenyataannya di Indonesia, watak postmodern ini memang menemukan gaungnya. Studi tentang kewalian Gus Dur di Jombang menunjukkan adanya niat dari pemerintah lokal di Jombang untuk menjadikan makam Gus Dur di Tebuireng sebagai destinasi wisata ziarah (religious tourism), di mana penziarahan tidak lagi dipandang dari sisi spiritualitasnya tetapi, juga menjadi ajang untuk menaikkan prestise Jombang dan menggenjot pendapatan ekonomi yang mungkin didapatkan dari ramainya peziarah di sana. ${ }^{17}$

15 N. Collins-Kreiner, "Researching Pilgrimage, Continuity and Transformations", dalam Annals of Tourism Research, Vol. 37, No. 2, 2010, 442-450.

${ }^{16}$ Ibid, 450-451.

17 Anwar Masduki, "The Tenth Saint": The Construction of Gus Dur's Sainthood (ThesisUniversity of Gadjah Mada, Yogyakarta, 2014). 


\section{Ziarah Wali, Pilgrimage Studies ala Indonesia}

Di Indonesia sendiri, terdapat banyak fenomena penziarahan yang bisa dijadikan bahan kajian. Mengingat Indonesia yang mengakui agama lokal maupun samawi yang mempunyai tradisi ziarah masingmasing, fenomena ziarah jelasnya bukan menjadi isu yang asing. Selain dalam Islam, ada banyak kajian dan penelitian yang telah dilakukan terkait ziarah umat Katolik, ${ }^{18}$ Hindu, $^{19}$ Budha $^{20}$ serta agama dan kepercayaan lokal. ${ }^{21}$ Fokus pada makalah ini akan lebih diberikan pada fenomena penziarahan umat Islam, utamanya ziarah Wali. Selain Islam memang menjadi mayoritas, pemilihan ziarah wali memang menjadi fokus penulis selama ini.

Konsep ziarah di kalangan Muslim Indonesia sendiri bersifat khusus dari kalangan umat agama lain. Ziarah Muslim di Indonesia secara umum lebih mendekati jenis yang dalam istilah kontemporer dalam pilgrimage studies yang disebut Dark pilgrimage, ${ }^{22}$ yakni sebuah penziarahan yang menghadiri situs-situs yang terkait dengan kematian,

${ }_{18}$ Contoh kajian ziarah umat Katolik, lihat R.L. Soemijantoro, Ziarah ke Gua Maria di Jawa (Jakarta: Dian Tirta, 2004); M. Budi Sarjono, Ziarah dari Sendangsono sampai Pub Sarang, Kediri; sebuah Renungan (Yogyakarta: Yayasan Pustaka Nusatama, 2002); Didit Meilena, Ritual Ziarah di Gua Maria Marganingsib, Dusun Ngaren, Paseban, Bayat, Klaten (Skripsi-Universitas Islam Negeri (UIN) Sunan Kalijaga, Yogyakarta, 2009).

19 Contoh kajian ziarah umat Hindu, meski kurang menyeluruh, ada pada bab-bab dalam buku Martin Ramsted (ed.), Hinduism in Modern Indonesia (London: Routledge, 2004); Brigitta Hauser-Schaublin, "Ritual, Pilgrimage and The Reconciliation of The State; Sacred Journeys In The Political Landscape of Bali (Indonesia)", dalam Jorg Gengnagel. et.al., Prozessionen, W allfahrten, Aufmärsche: Bewegung zwischen Religion und Politik in Europa und Asien seit dem Mittelalter, (Koln: Böhlau Verlag Köln Weimar, 2008), 288311.

${ }^{20}$ Contoh kajian ziarah umat Budha bisa dibaca dalam John Miksic, et.al., Borobudur, Golden Thales of the Buddha (Tokyo: Tuttle Publishing, 1990).

21 Contoh kajian ziarah agama dan kepercayaan lokal yang cukup lengkap ada di bukunya Henry Chambert-Loir dan Anthony Reid (ed), the Potent Dead; Ancestors, Saints and Heroes in Contemporary Indonesia (Hawaii: University of Hawaii Press, 2002); lihat juga Huub De Jonge, "Pilgrimages and Local Islam on Java," dalam Studia Islamika, Vol. 2, No. 5, 1998.

${ }^{22}$ Collins-Kreiner, "Researching Pilgrime," 445. 
bencana ataupun lokasi yang wingit. Studi tentang ziarah Wali di Indonesia merentang lebar dari mulai kajian tentang tradisi, budaya, agama maupun sosial ekonomi dan politik. Berdasarkan itu, rasanya sangat perlu untuk mengelompokkan kajian-kajian itu berdasarkan kerangka pendekatan paradigmatis yang dipakai oleh para peneliti ziarah di Indonesia. Pengelompokan ini penting untuk: (1) memetakan kecenderungan dari pendekatan baik teoretis maupun praksis yang muncul, (2) mengetahui aspek dominan dalam kajian ini, dan (3) menilai ceruk kajian yang masih bisa dielaborasi lebih jauh terkait ziarah wali ini.

\section{Klasifikasi pendekatan penelitian dalam kajian Ziarah Wali di Indonesia}

1. Pendekatan sosio-religius

Meski banyak dilakukan, Isu ziarah wali di Indonesia masih merupakan isu yang belum direspons secara seragam oleh seluruh umat. Ada pelbagai pro dan kontra yang mewarnai, sejalan dengan kesejarahan fenomena ziarah wali sejak dulu. ${ }^{23}$ Pendekatan sosio-religius di sini lebih mendekati apa yang diteliti oleh sosiologi dan antropologi agama, di mana isu krusial yang diteliti meliputi legitimasi ajaran agama, legitimasi ritual yang dilakukan dan legitimasi budaya oleh masyarakat sekitar lokasi penziarahan.

Legitimasi-legitimasi itu menjadi sangat penting karena di situlah kita bisa mengetahui dan memahami posisi penziarahan dalam ajaran Islam dan yang lebih penting lagi adalah untuk mengetahui keabsahan dari praktik-praktik tersebut dipandang dari sumber teks agama dan reaksi masyarakat terhadap teks tersebut. Keabsahan di sini bisa dilihat dari penelusuran terhadap teks yang mendasari dan/atau membolehkan adanya praktik ziarah, serta bagaimana pemahaman orang/peziarah terhadap praktik ziarah yang mereka lakukan. ${ }^{24}$

\footnotetext{
${ }^{23}$ Henry Chambert-Loir dan Claude Guillot (eds.), Ziarah dan Wali di Dunia Islam (Depok: Komunitas Bambu, 2010).

${ }^{24}$ Contoh kajian yang termasuk dalam pendekatan ini di antaranya adalah M. Hanif Muslih, Kesahiban Dalil Ziarah Kubur menurut al-Qur'an dan al-Hadits (Semarang: Al-Ridha,
} 


\section{Pendekatan Sosio-Linguistik}

Bahasa menjadi salah satu elemen penting dalam studi ziarah wali di Indonesia. Terkait praktik dan bahasa sehari-hari yang digunakan oleh peziarah, ini menunjukkan adanya kekhususan khusus yang biasanya berkembang mengikuti fenomena penziarahan yang terjadi. Selain sebagai penanda khusus, bahasa juga menunjukkan keumuman yang bisa dijumpai dalam setiap masyarakat maupun lokasi ziarah yang dilakukan. Bahasa, menjadi wacana umum dan khusus yang selalu mewarnai dan memberi tanda dari keseharian masyarakat itu sendiri.

Jamhari $^{25}$ meneliti adanya perbedaan operasional antara "barakah" dengan "perolehan" yang dia temukan di penziarahan Sunan Bayat, Klaten. Bagi para peziarah di sana, meski barakah dan perolehan sama-sama adalah hasil dari ziarah yang mereka lakukan, ada perbedaan mendasar yang tidak bisa dikesampingkan. Kata 'barakah' merujuk pada hasil yang lebih bersifat pada kepuasan batiniah dan pastinya 'baik' dalam pemahaman agama dan ekses sehari-hari, sementara 'perolehan' cenderung mereka pahami sebagai hasil yang lebih bersifat duniawi dan karenanya bersifat kurang baik atau 'panas' bagi kehidupan mereka sehari-hari.

Selain pemahaman para peziarah, yang tidak bisa dilupakan juga terkait kebahasaan dan istilah yang muncul dari konsepsi ziarah dan Wali itu sendiri. Dalam literatur yang begitu banyak mengenai Wali, kita mengenal banyak sekali kategori Wali yang diajukan oleh banyak ulama atau cendekiawan Muslim. Penelitian tentang Wali Majzub atau yang biasa disebut Wali Sufi Gila oleh Masyhudi ${ }^{26}$ memberikan contoh betapa penamaan dan istilah Wali juga sangat kaya dan beragam, merentang dari istilah sufisme sampai istilah non-sufisme yang bisa dijumpai dalam literatur.

2009); Muhammad Mahir Al-Buhairi, Ziarah Kubur (Surakarta: Ziyad Book, 2009); M. Rofiq Junaidi, Hadis dalam Tradisi (Studi Analisis terbadap Periarah Makam KH. Abdurrahman Wabid) (Tesis-Universitas Islam Negeri (UIN) Sunan Kalijaga, 2012); Ali Jum'ah, Alangkah Indahnya Bid'ah Ini (Yogyakarta: Ansana Pustaka, 2010).

${ }^{25}$ Jamhari, "The Meaning Interpreted: The Concept of Barakah in Ziarah", dalam Studia Islamika, Vol. 8, No. 1, 2001, 87-128.

${ }^{26}$ In'amuzzahidin Masyhudi, Wali Sufi Gila (Yogyakarta: Ar-Ruzz, 2002). 
Selain dalam literatur, kita juga akan dengan mudah mengenali penamaan antara wali yang berbeda-beda dan biasanya disandarkan pada asal tempat dan makam atau atribut khusus sang Wali. Contohnya, kita mengenal sebutan $W$ ali Songo untuk menyebut Sembilan wali di Jawa, Wali Pitu untuk tujuh wali di Bali, Sunan Bayat untuk merujuk Sunan Pandanaran yang dimakamkan di Bayat, Sunan Ampel untuk Raden Rahmat yang dimakamkan di Ampel, Sunan Kudus untuk Raden Ja'far Shodik yang dimakamkan di Kudus, dan yang paling terbaru tentu saja ada nama Wali Kesepuluh untuk Gus Dur di Tebuireng, Jombang. ${ }^{27}$

3. Pendekatan Sosio-Ekonomi

Seperti disinggung di muka, fenomena ziarah dan pariwisata (tourism) sudah menjadi fenomena yang dianggap hampir sama. Perjalanan, mobilitas ataupun sirkulasi para peziarah dari tempat asalnya ke daerah lain yang ada makam atau tempat yang dikeramatkan memang hampir mirip dengan fenomena wisata, di mana orang dengan suka hati melakukan perjalanan jauh untuk mengunjungi tempat-tempat wisata di penjuru dunia. Kesamaan 'perjalanan' ini yang juga membuat orang kemudian mengenal istilah 'pilgrimage tourism' 28 atau 'wisata rohani'. Di Indonesia ini, sudah sering kita jumpai istilah 'wisata rohani' yang berisi tur atau perjalanan 3-5 hari untuk mengunjungi makam-makam Wali, utamanya makam para Wali Songo di Pulau Jawa.

Ekses dari sisi pariwisata dan ziarah terkait dengan kepentingan ekonomis yang kemudian ikut memainkan peranan penting dalam perkembangan praktik ziarah di suatu tempat. Semakin ramainya jumlah peziarah yang datang, semakin banyak pula orang yang berusaha mencari atau mendapatkan keuntungan finansial dari sana. Quinn ${ }^{29}$ memberi ulasan yang sangat meyakinkan betapa ziarah berkait erat dengan

\footnotetext{
${ }^{27}$ Masduki, "The Tenth Saint".

${ }^{28}$ Lihat misalnya William H. Swatos and Luigi Tomasi (ed.), From Medieval Pilgrimage to Religious Tourism: the Social and Cultural Economics of Piety (Westport, CT: Praeger, 2002).

29 George Quinn, "Throwing Money at The Holy Door; Commercial Aspects of Popular Pilgrimage in Indonesia," dalam Greg Fealy and Sally White (eds.), Expressing Islam: Religious Life and Politics in Indonesia (Singapore: Institute of Southeast Asian Studies, 2007), 63-79.
} 
munculnya kepentingan dan motif ekonomis dibalik fenomena spiritual ini dengan menyatakan:

Money and pilgrimage go together. In fact, it is the central argument of this chapter that not only is pilgrimage an increasingly significant component of the domestic travel economy in Java, but commercial transactions in the marketplace of pilgrimage are also metaphorical actions that parallel devotional ritual and illuminate the relationship between believer and God. ${ }^{30}$

4. Pendekatan Sosio-Politik

Legitimasi dan pencapaian politik kekuasaan menjadi salah satu tujuan yang ingin direngkuh seseorang dengan medium ziarah. Pada era Gus Dur menjadi Presiden, kunjungan ziarah ke makam baik wali maupun ulama di masa itu menjadi isu yang umum diketahui, mengingat kegemaran Gus Dur yang suka 'mendengarkan suara langit'. ${ }^{31}$ Lebih jauh, Quinn ${ }^{32}$ juga memotret penziarahan 'politis' yang dilakukan oleh para presiden Indonesia yang berasal dari Jawa.

Melakukan kunjungan ziarah dengan nuansa politis bukan monopoli para politisi jaman sekarang. Pada masa lalu, Sultan Agung juga pernah melakukan penziarahan ke makam Sunan Bayat di Klaten ${ }^{33}$ untuk merangkul kalangan Islam yang suka memberontak padanya. Dengan melakukan ziarah, ini menjadi bukti dari pengakuan Sultan Agung kepada tradisi Muslim wilayahnya sehingga diharapkan bisa mendinginkan suasana dan bahkan mendapatkan dukungan politis dari rakyatnya, dan terutama sekali dari elit dan pemuka agama Islam di pulau Jawa.

Selain digunakan untuk menjadi legitimasi politis, teropong kajian ziarah juga bisa menjadi analisis untuk mengamati ekspresi sosio-politis masyarakat melalui aktivitas ziarah mereka. Mini riset dari Quinn tentang

\footnotetext{
${ }^{30}$ Ibid, 64.

${ }^{31}$ Chambert-Loir Ana Reid, the Potent Dead, xv-xvi.

32 George Quinn, "National Legitimacy through a Regional Prism: Local Pilgrimage and Indonesia's Javanese Presidents," dalam Minako Sakai, Greg Banks and John Walker (eds.), the Politics of the Periphery in Indonesia: Social and Geographical Perspectives (Singapore: NUS Press, 2009), 173 - 199.

33 M.C. Ricklefs, Polarising Javanese Society, Islamic and other visions (c. 1830 - 1930) (Singapore: NUS Press, 2007) 3.
} 
penziarahan di makam Cut Nyak Dien ${ }^{34}$ menunjukkan adanya ekspresi para peziarah terkait aspirasi kemerdekaan Aceh, atau bahkan dipakai sebagai legitimasi untuk menjamin tetap bergabungnya Aceh ke dalam Negara Kesatuan Republik Indonesia.

\section{Aspek-aspek penting dalam kajian Ziarah Wali Indonesia}

Berdasarkan pendekatan dan praksis penelitian yang telah ditemukan di atas, selanjutnya akan lebih mudah bagi kita untuk mengetahui aspek-aspek penting apa saja yang terkait dalam kajian ziarah wali di Indonesia. Setidaknya, ada 5 (lima) aspek penting yang akan selalu ada dan mewarnai, yakni aspek sejarah, geografi, ekonomi, politik dan religius.

1. Sejarah

Aspek kesejarahan adalah aspek yang selalu terkait dengan fenomena ziarah Wali. Indikasi ini terutama sangat kentara jika kita mengamati bertebarannya buku-buku yang menceritakan sejarah Wali Songo sebagai penyebar Islam tersukses di Pulau Jawa di masa lalu. Hampir tidak bisa dilepaskan antara kaitan historis para Wali di masa lalu dengan penghormatan yang mereka terima dari masyarakat selama ini. Aspek historis bisa digunakan untuk melegitimasi pengaruh dan kepantasan seseorang untuk disebut Wali atau tidak.

Dalam rangka itu, Sunyoto ${ }^{35}$ menjelaskan dengan sangat rinci mengenai autentisitas ajaran Islam para wali di jaman dahulu, untuk menangkal serbuan dan usaha-usaha kaum muslim lain yang tidak mengakui praktik ziarah sebagai salah satu ajaran Islam. Baginya, ritual dan penghormatan para peziarah di makam-makam wali itu selaras dengan ajaran awal Jawa yang disebutnya Kapitayan, dan menekankan betapa para wali datang dan menyebarkan Islam dengan merangkul nilai dan filosofi lokal untuk dipadu-padankan dengan nilai dan ajaran Islam

\footnotetext{
${ }^{34}$ George Quinn, Diplomasi Kubur: Makam Cut Nyak Dien dan Upaya Menyelesaikan Konflik di Aceh (Beranda PPIA, no.1, June 2005), 4-8.

35 Agus Sunyoto, Wali Songo: Rekonstruksi Sejarah yang Disingkirkan (Jakarta: Transpustaka, 2011).
} 
yang universal. Wali Songo, dengan demikian menjadi sah untuk diklaim sebagai peletak dasar Islam yang mengindonesia, sehingga menjadi sangat tidak masuk akal bagi sebagian kalangan muslim yang menolak peran kesejarahan Wali Songo dan terang-terangan ingin menghapusnya dalam catatan sejarah Islam Indonesia ini.

\section{Geografi}

Aspek geografis atau lokasi penziarahan juga menjadi sisi yang tidak bisa dilepaskan. Setidaknya, dengan bentuk kepulauan di negeri ini, ada perbedaan karakteristik, baik waktu, denah lokasi maupun rute yang harus ditempuh. Ada makam yang bisa ditempuh secara mudah, karena terletak di tengah kota besar seperti Ampel di Surabaya, atau Bonang di Tuban, tetapi ada juga makam wali yang terletak jauh tinggi di atas gunung seperti makam Sunan Muria di Gunung Muria, Jepara, atau makam Sunan Bayat di Klaten.

Secara sederhana, aspek geografis dari penziarahan di Indonesia bisa dikumpulkan dalam 2 (dua) kategori besar, yakni ziarah wali di Jawa dan di luar Jawa. Untuk kategori yang pertama, Wali Songo menjadi primadona, merentang dari Ampel di Jawa Timur sampai ke Cirebon di Jawa Barat. Menariknya, mayoritas dari makam Wali Songo ini terletak di pesisir utara Pulau Jawa, dengan variasinya masing-masing. Wali-wali yang berada di pertengahan (mainland) seperti Sunan Bayat di Klaten, ataupun pesisir selatan Jawa seperti Syekh Abdul Muhyi di Pamijahan, Tasikmalaya masih menjadi destinasi berikutnya setelah Wali Songo yang mayoritas di pesisir utara itu. Selain dua kelompok wilayah ini, masih banyak dijumpai adanya makam orang yang dianggap wali, meski tidak seramai kunjungan di dua kelompok wali yang telah disebutkan itu.

Kategori luar Jawa mencakup penziarahan di Pulau Madura, Bali, Sumatera, Nusa Tenggara, Sulawesi dan Kalimantan. Dibandingkan dengan kajian ziarah di Jawa, masih sedikit sekali kajian yang dilakukan di kelompok kedua ini. Kalaupun ada, itu masih berupa kajian parsial dan tidak semasif kajian-kajian yang dilakukan. Contoh misalnya, Quinn ${ }^{36}$ mengangkat fenomena ziarah di Bali, dengan menelusuri kaitan historis,

${ }^{36}$ George Quinn, "The Muslim Saints of Bali," makalah dalam Bali in Global Asia Conference, Udayana University, Denpasar, July 16-18, 2012. 
cerita lokal, rute dan biaya perjalanan ziarah ke sana. Yang menarik dari makalah Quinn adalah adanya anggapan bahwa penziarahan di Bali merupakan salah satu bentuk nyata toleransi dari pemeluk mayoritas Hindu Bali terhadap praktik agama Islam. Pastinya, fenomena toleransi ini tidak bisa ditemui di Jawa, mengingat di Islam di Jawa adalah mayoritas dan praktik ziarah sudah menjadi fenomena keseharian.

3. Ekonomi

Aspek ekonomi menjadi penanda lain dari fenomena ziarah Wali yang kebanyakan sifatnya adalah turunan. Artinya, aspek ekonomi akan cenderung mengikuti fenomena penziarahan, semakin ramai suatu objek ziarah, maka akan semakin meningkat pula aktivitas ekonomi yang terjadi. Perkembangan pasar dan pedagang kaki lima di sekitar pesantren Tebuireng setelah pemakaman Gus Dur menguatkan hal ini. ${ }^{37}$ Jika dulu di kompleks Tebuireng hanya berisi beberapa gelintir pedagang di belakang pesantren, sekarang hampir seluruh gang di belakang, samping dan bahkan depan pesantren menjadi penuh dengan pedagang yang menjajakan dagangan mereka. Yang dijajakan juga beragam, mulai dari pakaian, kaos, peci, buku sampai ke makanan dan minuman. Selain itu, terdapat juga parkir dadakan dan ponten-ponten yang menawarkan jasa untuk para peziarah yang butuh memarkirkan motor atau kendaraan maupun untuk membuang hajat kecil saja.

Selain ekses terhadap masyarakat sekitar, fenomena ziarah juga tidak bisa mengesampingkan perkembangan infrastruktur dan alat transportasi yang semakin mudah dan terjangkau secara ekonomis. Ziarah, utamanya yang berupa tur perjalanan 3-5 hari tentu saja menghabiskan dana yang tidak sedikit. Dana itu terpakai untuk menyewa bus atau mobil dan juga untuk bekal dan membeli oleh-oleh. Karena itu, selain menjadi berkah bagi para pedagang di sekitar penziarahan, fenomena ziarah juga menguntungkan bagi pemerintah yang menarik pajak retribusi (biasanya dari parkir kendaraan) dan juga para pengusaha angkutan transportasi atau agen-agen dan biro wisata perjalanan. Bisa dipahami kemudian, ini menjadi lading bisnis tersendiri. Banyak agen dan biro wisata yang menyediakan paket wisata ziarah dengan biaya tertentu

${ }^{37}$ Masduki, "The Tenth Saint,” 55-56. 
yang harus dibayarkan oleh orang yang ingin melakukan ziarah, dengan jaminan kenyamanan dan ketepatan jadwal.

4. Politik

Politik, menjadi salah satu aspek dan faktor determinan dalam fenomena ziarah. Menariknya, fenomena politik ini tidak hanya menjadi monopoli para penguasa, baik nasional sebagaimana yang telah dipotret oleh Quinn, ${ }^{38}$ tetapi juga para penguasa lokal dan bahkan keluarga sang Wali sendiri, terutama terkait dengan pemeliharaan dan penjagaan situs makam masing-masing.

Dari studi kasus di Jombang, ${ }^{39}$ membludaknya peziarah di makam Gus Dur telah mengundang inisiatif Pemkab Jombang untuk turut serta membantu dan menyediakan sarana dan prasarana yang dibutuhkan untuk menunjang kelancaran dan kenyamanan peziarah. Motif ekonomi adalah motif yang paling kentara dari campur tangan pemerintah dalam urusan pengembangan dan pembaharuan situs makam, mengingat pemerintah Jombang memang berkeinginan membuat perencanaan adanya Wisata Ziarah di Tebuireng. Akan tetapi, motif ekonomi ini juga tidak bisa menutupi kecenderungan politis pemerintah Jombang untuk semakin menguatkan pengaruh dan memenangkan hati masyarakat Jombang. Hal itu tampak sekali dengan penggantian nama jalan nasional di kota Jombang yang segera berganti menjadi Jl. KH Abdurrahman Wahid atau Jalan Gus Dur, sebagai usaha untuk mengakomodasi aspirasi masyarakat Jombang itu. Dengan kepedulian ini, tentu saja pemerintah Jombang berharap bahwa masyarakat Jombang akan merasa dihargai dan sebagai umpan baliknya, masyarakat akan lebih mendukung program pemerintah di sana.

Selain kekuasaan yang sifatnya formal, aspek politik dari sebuah penziarahan tidak bisa mengesampingkan peran para pemelihara situs atau juru kunci. Fox ${ }^{40}$ menunjukkan bahwa power (kekuasaan) dari juru

\footnotetext{
38 George Quinn, "National Legitimacy".

39 Masduki, "The Tenth Saint," 51-53.

40 James J Fox, "Interpreting the Historical Significance of Tombs and Chronicles in Contemporary Java", dalam Greg Fealy and Sally White (eds.), Expressing Islam: Religious Life and Politics in Indonesia (Singapore: Institute of Southeast Asian Studies, 2007), 60.
} 
kunci atau pemelihara makam memegang 3 (tiga) hal dasar dari sebuah penziarahan, yakni tuntunan, mediasi dan pemaknaan. Melalui peran merekalah, aktivitas ziarah di suatu tempat dijaga, dilestarikan dan diterjemahkan ke dalam kehidupan keseharian. Jamhari menunjukkan bahwa kuncen di Makam Sunan Bayat menjadi tempat konsultasi dan diskusi terkait mimpi atau pertanda yang didapat oleh peziarah dalam laku ziarah mereka. ${ }^{41}$ Di makam Kiai Hamid Pasuruan, pengelola memberi aturan resmi terkait ritual dan apa-apa yang harus dihindari oleh peziarah di sana. ${ }^{42}$ Peran-peran seperti inilah yang membuat para juru kunci dan pemelihara makam itu menjadi sentral dan pemegang kekuasaan politis yang menentukan dalam perkembangan dan perubahan di setiap situs ziarah.

\section{Religius}

Aspek keagamaan merupakan aspek yang paling melekat dari praktik dan kajian ziarah wali di Indonesia. Ritual dalam ziarah itu sendiri menjadi penanda yang paling kentara dari aspek keagamaannya. Pembacaan $\operatorname{tah}\}$ lîl, tah\}mîd maupun s\}alâwât dan al-Qur'ân menjadi beberapa kegiatan wajib atau pasti yang dilakukan oleh para peziarah di makam para wali.

Ritual itu sendiri tidak bisa dilepaskan dari niat atau motif yang mendasari para peziarah melakukan ritual ataupun ziarah itu sendiri. Ada kesepakatan umum bahwa para peziarah ini melakukan ziarah untuk memperoleh berkah atau karomah para wali dan melakukan tawasul kepada para wali. Berkah atau karomah dan tawasul ini menjadi 2 (dua) isu penting yang tidak bisa dilepaskan dari aspek pemahaman religius yang dipercayai para peziarah. Dengan memperoleh berkah, para peziarah mempercayai dan berharap untuk ikut memperoleh karomah yang dipunyai para wali. Dengan tawasul, para peziarah menepis

\footnotetext{
${ }^{41}$ Jamhari, The Meaning Interpreted, ibid.

${ }^{42}$ Badruddin, Pandangan Peziarah Terhadap kewalian Kyai Abdul Hamid Bin Abdullah Bin Umar Basyaiban Pasuruan Jawa Timur: Persepektif Fenomenologis (Disertasi-Institut Agama Islam Negeri (IAIN) Sunan Ampel Surabaya, 2011).
} 
anggapan para pencela ziarah yang menganggap mereka menganggap perbuatan ziarah mereka sebagai musyrik dan atau penyembah kuburan. ${ }^{43}$

\section{Penutup}

Kajian terhadap ziarah wali di Indonesia merupakan salah satu bagian integral dalam pilgrimage studies. Integralitas tersebut mengemuka dalam pendekatan dan aspek-aspek yang senada dengan kajian ziarah di belahan dunia yang lain. Satu contoh yang kentara, dekatnya fenomena ziarah dengan fenomena wisata menjadi bukti bahwa kajian di Indonesia selalu selaras dengan tren terkini dari pilgrimage studies yang ada di belahan dunia lain, yang mulai melihat kemiripan antara aktivitas ziarah dengan aktivitas wisata (tourism).

Sebagaimana pilgrimage studies yang bersifat multidisipliner, kajian ziarah wali di Indonesia juga berupa kajian multi-disipliner yang melibatkan multi pendekatan, dari pendekatan sosio-religius sampai sosio-politik saling berjalin kelindan. Meski semua pendekatan itu jarang sekali terkumpul dalam suatu kajian terhadap satu penziarahan di makam wali tertentu, minimal ada dua atau tiga pendekatan yang biasanya dipakai oleh peneliti untuk mengkajinya. Hal ini memang tidak bisa dipungkiri, mengingat kajian ziarah selalu melibatkan dua kutub utama kehidupan beragama manusia, yakni aspek duniawi/material dan ukhrawi/spiritual.

43 Baru-baru ini, pertengahan September 2014, Kementerian Agama terpaksa menarik ulang buku pelajaran sejarah yang dijadikan panduan pembelajaran di tingkatan Tsanawiyah (setara SMP), karena ada salah satu soal materi yang menyebut bahwa praktik ziarah wali adalah praktik menyembah kuburan yang dikategorikan musyrik. Penarikan ini dilakukan setelah mendapat reaksi keras dari kaum muslim yang terbiasa melakukan ziarah dengan menyatakan bahwa ziarah yang mereka lakukan bukanlah perbuatan musyrik menyembah kuburan, melainkan usaha tawasul, yakni berdoa kepada Allah Swt. dengan perantaraan para wali, dengan harapan doanya akan berpeluang untuk cepat terkabul karena kedekatan para wali dengan Tuhan. lihat misalnya http://www.suarasahabat.com/2014/09/18/kemenag-menarik-peredaran-buku-sejarah -kebudayaan-islam/, diakses 27 Oktober 2014; http://www.jpnn.com/read/2014/09/17/258395/PKB-Desak-Kemenag-Tarik-Buku-SKI-dari-Peredaran-, diakses 27 Oktober 2014; $\quad$ http://news.detik.com/read/2014/09/17/161628/2693083/10/kemenag-akan-revisi-buku-yang-sebut-makam-wali-adalah-berhala-dalam-3-hari, diakses 27 Oktober 2014. 
Dua aspek inilah yang selalu membuat kajian ziarah bersifat multidisiplin, agar gambaran yang diperoleh lebih menyeluruh dan mengkover mayoritas aspek yang saling terkait dalam fenomena ziarah.

Pada sisi lain, menggali dan memperhatikan dengan saksama tentang kajian Wali di Indonesia, kita akan menemukan sebuah lubang besar yang muncul dari ketimpangan lokasi dan figur yang diteliti. Di sini, gugatan terhadap dominasi kajian ziarah Wali di Jawa menjadi sahih untuk dimunculkan. Mengapa dan bagaimana mayoritas para peneliti hanya bergulat dengan fenomena ziarah wali di Jawa dan kurang memperhatikan ziarah Wali di luar Jawa. Padahal, Islam Indonesia tidak hanya eksis atau terbatas di Jawa saja, ia menyebar di banyak pulau di luaran jawa. Sumatera, Kalimantan, Sulawesi, Nusa tenggara dan bahkan Papua juga ikut memberikan ciri khas dan sumbangan penting bagi corak keislaman keindonesiaan. Ziarah Wali pun, banyak dan ada di masingmasing pulau tersebut, sehingga sangat mengherankan jika fenomenafenomena itu masih kurang mendapatkan porsi yang lebih untuk dikaji.

Argumen sementara yang bisa dimunculkan adalah bahwa hegemoni Jawa di Indonesia memang telah sedemikian kuat dan nyaris tak terbendung, dan itu termasuk dalam kajian ziarah wali di Indonesia. Kecenderungan peneliti untuk lebih melihat Jawa sebagai sebuah gambaran Islam yang mengindonesia disinyalir menjadi lubang besar yang menyisakan pekerjaan rumah untuk dijawab terutama oleh para pemerhati kajian ziarah di Indonesia sendiri. Minimnya literatur yang membahas fenomena kajian di luar Jawa menjadi peluang untuk diangkat dalam penelitian selanjutnya. Tentu saja, hasil dari penelitian itu akan semakin memperkaya khazanah kajian ziarah di Indonesia ini, dan pemahaman yang lebih menyeluruh terhadap Islam di Indonesia.

\section{Daftar Pustaka}

Al-Buhairi, Muhammad Mahir. Ziarah Kubur. Surakarta: Ziyad Book, 2009.

PKB desak Kemenag tarik buku SKI dari peredaran, Rabu, 17 September 2014, http://www.jpnn.com/read/2014/09/17/258395/PKB-Desak-Kemenag-Tarik-Buku-SKI-dari-Peredaran- 
Badone, Ellen and Roseman, Sharon R. (eds.). Intersecting Journeys: the Anthropology of Pilgrimage and Tourism. Illionis: University of illionis Press, 2004.

Badruddin, Pandangan Peziarah Terbadap kewalian Kyai Abdul Hamid bin Abdullah bin Umar Basyaiban Pasuruan Jawa Timur: Persepektif Fenomenologis. Disertasi-Institut Agama Islam Negeri (IAIN) Sunan Ampel Surabaya, 2011.

Bharati, Agehananda. "Theoretical Approaches to the Anthropology of Pilgrimage". Dalam Mahipal Buriya dan S.M. Michael (eds.). Anthropology as a Historical Science. Indore, India: Sat Prakashan Sanchar Kendra, 1984.

Bhardwaj, S.M. and Rinschede, G. (eds.). Pilgrimage in World Religion. Berlin: Reimer, 1988.

Chambert-Loir, Henry and Reid, Anthony (eds.). The Potent Dead; Ancestors, Saints and Heroes in Contemporary Indonesia. Hawaii: University of Hawaii Press, 2002.

Chambert-Loir, Henry dan Guillot, Claud (eds.). Ziarah dan Wali di Dunia Islam. Depok: Komunitas Bambu, 2010.

Collins-Kreiner, N. "Researching Pilgrimage, Continuity and Transformations". Dalam Annals of Tourism Research. Vol. 37, No. 2, 2010 .

De Jonge, Huub. "Pilgrimages and Local Islam on Java". Dalam Studia Islamika. Vol 2, No. 5, 1998.

Eade, Jhon. "The Expanding Field of Pilgrimage Studies: Beyond Binaries, Commentary". Dalam Journal of Tourism. Vol. 59 No. 3, 2011.

- Jhon dan Sallnow, Michael J. Contesting the Sacred, the Anthropology of Pilgrimage. Illionis: University of Illionis Press, 2000.

Fox, James J. "Interpreting the Historical Significance of Tombs and Chronicles in Contemporary Java". Dalam Greg Fealy and Sally 
White (eds.). Expressing Islam: Religious Life and Politics in Indonesia. Singapore: Institute of Southeast Asian Studies, 2007.

Hauser-Schaublin, Brigitta. "Ritual, Pilgrimage and the Reconciliation of The State; Sacred Journeys in the Political Landscape of Bali (Indonesia)". Dalam Jorg Gengnagel. et.al, Prozessionen, Wallfahrten, Aufmärsche: Bewegung wwischen Religion und Politik in Europa und Asien seit dem Mittelalter. Koln: Böhlau Verlag Köln Weimar, 2008.

Jamhari. "The Meaning Interpreted: the Concept of Barakah in Ziarah". Dalam Studia Islamika. Vol. 8, No. 1, 2001.

Jum'ah, Ali. Alangkah Indahnya Bid'ah Ini. Yogyakarta: Ansana Pustaka, 2010.

Junaidi, M. Rofiq. Hadis dalam Tradisi: Studi Analisis terbadap Pęiarah Makam KH. Abdurrahman Wahid. Tesis-Universitas Islam Negeri (UIN) Sunan Kalijaga, 2012.

Kemenag akan revisi buku yang sebut makam wali adalah berhala dalam 3 hari, Rabu, 17 September 20140, http://news.detik.com/read $/ 2014 / 09 / 17 / 161628 / 2693083 / 10 /$ kemenag-akan-revisibuku-yang-sebut-makam-wali-adalah-berhala-dalam-3-hari.

Masduki, Anwar. "The Tenth Saint": The Construction of Gus Dur's Sainthood. Thesis-University of Gadjah Mada (UGM), Yogyakarta, 2014.

Masyhudi, In'amuzzahidin. Wali Sufi Gila. Yogyakarta: Ar-Ruzz, 2002.

Meilena, Didit. Ritual Ziarah di Gua Maria Marganingsib, Dusun Ngaren, Paseban, Bayat, Klaten. Skripsi-Universitas Islam Negeri (UIN) Sunan Kalijaga, Yogyakarta, 2009.

Miksic, John, et.al. Borobudur, Golden Thales of The Buddha. Tokyo: Tuttle Publishing, 1990.

Muslih, M. Hanif. Kesabihan Dalil Ziarah Kubur menurut al-Qur'an dan alHadits. Semarang: Al-Ridha, 2009.

Quinn, George. "Throwing Money at The Holy Door; Commercial Aspects of Popular Pilgrimage in Indonesia". Dalam Greg Fealy 
and Sally White (eds.). Expressing Islam: Religious Life and Politics in Indonesia. Singapore: Institute of Southeast Asian Studies, 2007.

"National Legitimacy through a Regional Prism: Local Pilgrimage and Indonesia's Javanese Presidents". Dalam Minako Sakai, Greg Banks and John Walker (eds.), The Politics of the Periphery in Indonesia: Social and Geographical Perspectives, Singapore: NUS Press, 2009.

. "The Muslim Saints of Bali," makalah dalam Bali in Global

Asia Conference, Universitas Udayana, Denpasar, 16-18 Juli 2012.

"Diplomasi Kubur: Makam Cut Nyak Dien dan Upaya Menyelesaikan Konflik di Aceh”. Dalam PPIA, no. 1, Juni 2005.

Kemenag menarik peredaran buku sejarah kebudayaan Islam, Kamis, 18 September 2014, http://www.suarasahabat.com/2014/09/18/kemenag-menarik-peredaran-buku-sejarah-kebudayaan-islam/

Ramsted, Martin (ed.). Hinduism in Modern Indonesia. London: Routledge, 2004.

Ricklefs, M.C. Polarising Javanese Society, Islamic and Other Visions (c. 1830 1930). Singapore: NUS Press, 2007.

Sarjono, M. Budi. Ziarah dari Sendangsono sampai Puh Sarang, Kediri: Sebuah Renungan. Yogyakarta: Yayasan Pustaka Nusatama, 2002.

Soemijantoro, R.L. Ziarah ke Gua Maria di Jawa. Jakarta: Dian Tirta, 2004.

Stoddard, Robert. "Defining and Classifying Pilgrimage", Paper 2, Nebraska: Geography Faculty Publication, 1997.

Sunyoto, Agus. Wali Songo: Rekonstruksi Sejarah yang Disingkirkan. Jakarta: Transpustaka, 2011.

Swatos, William H. dan Tomasi, Luigi (eds.). From Medieval Pilgrimage to Religious Tourism: the Social and Cultural Economics of Piety. Westport, CT: Praeger, 2002. 
Tanaka, Hiroshi. "On the Geographic Study of Pilgrimage Places". Dalam S.M. Bhardwaj dan G. Rinschede (eds.). Pilgrimage in World Religion. Berlin: Reimer, 1988.

Turner, Victor W. The Ritual Process, Structure and Anti-structure, $2^{\text {nd }}$ edition. New Jersey: Transaction Publication, 2008. . "The Center Out There: Pilgrim's Goal”. Dalam Journal History of Religions, Vol. 12, 1973. 